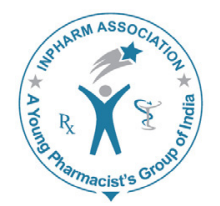

\title{
JITP
}

\section{Anti-inflammatory Activities of Total Leaf Extracts of Ficus sycomorus L. (Moraceae) used in Traditional Medicine in the Treatment of Sickle Cell Disease}

\author{
Alphonsine Ramdé-Tiendrébéogo ${ }^{1,2}$, Noufou Ouédraogo ${ }^{2}$, André Tibiri ${ }^{2,4^{*}}$, \\ Odile Germaine Nacoulma ${ }^{1}$, and Innocent Pierre Guissou ${ }^{2,3}$ \\ ${ }^{1}$ Laboratoire de Biochimie et de Chimie Appliquées (LABIOCA)/Unité de Formation et de Recherche en \\ Sciences de la Vie et de la Terre (UFR/SVT), Université de Ouagadougou, 09 BP 848 Ouagadougou 09, \\ Burkina Faso.
}

2Département de Médecine et Pharmacopée Traditionnelles-Pharmacie/Institut de Recherche en Sciences de la Santé (MEPHATRA-PH/IRSS), 03 BP 7192 Ouagadougou 03, Burkina Faso.

${ }^{3}$ Laboratoire de Pharmacologie-Toxicologie/Unité de Formation et de Recherche en Sciences de la Santé (UFR/SDS), Université de Ouagadougou, 03 BP 7021 Ouagadougou 03, Burkina Faso.

${ }^{4}$ Unité Mixte Internationale-Environnement, Santé, Sociétés (UMI 3189, ESS)-CNRS/UCAD/USTTB/CNRST/ $U G B$.

\begin{abstract}
Background: This study has been carried out to evaluate the in vivo anti-inflammatory, analgesic and anti-pyretic effects of an aqueous decoction and ethanol extract (95\%) of Ficus sycomorus leaves. Methods: The anti-inflammatory effect was evaluated by the carrageenan-induced mice paw oedema model. The non-morphine type analgesic effect was evaluated trough acetic acid-induced writhing test. The morphine type analgesic activity was tested by mouse tail-flick test. The anti-pyretic activity was tested by induced hyperthermia in mice with brewer's yeast. Data analysis used the one way ANOVA test. Results: The anti-inflammatory effects of the two extracts, at doses of 300 and $500 \mathrm{mg} / \mathrm{kg}$ b.w., were dose dependent and comparable to those of the reference controls, indomethacin (1 mg/kg b.w.) and hydrocortisone $(10 \mathrm{mg} / \mathrm{kg} \mathrm{b.w.})$. At the same dose, the analgesic effect of the ethanol extract on abdominal writhings induced by acetic acid, was comparable to those Lysine acetylsalicylate (LAS, $300 \mathrm{mg} / \mathrm{kg} \mathrm{b.w)} \mathrm{and} \mathrm{hydrocortisone} \mathrm{(10} \mathrm{mg/kg} \mathrm{b.w.)} \mathrm{used} \mathrm{as}$ controls. As for the morphine type analgesic effects of the two extracts tested at doses of 300 and $500 \mathrm{mg} / \mathrm{kg}$ both were significantly higher in comparison with the blank control $(p<0.05)$ and comparable to that of morphine $(5 \mathrm{mg} / \mathrm{kg} \mathrm{b.w.)}$ from the $75^{\text {th }}$ minute. The antipyretic activity of the extracts at the same doses was comparable to those of the LAS ( $300 \mathrm{mg} /$ $\mathrm{kg}$ b.w.) and hydrocortisone (10 $\mathrm{mg} / \mathrm{kg}$ b.w.) from the third hour. Conclusion: The results obtained justify the use of the plant in traditional medicine and show the significance of Ficus sycomorus leaves in the search for new anti-inflammatory molecules in the treatment of sickle cell disease.
\end{abstract}

Key words: Anti-inflammatory, Analgesic, Antipyretic, Antinociceptive, Ficus sycomorus, Sickle cell disease.

\begin{tabular}{|c|c|}
\hline \multicolumn{2}{|c|}{ Access this article online } \\
\hline Journal Sponsor & \multirow[b]{2}{*}{$\begin{array}{l}\text { Website: } \\
\text { www.jyoungpharm.org }\end{array}$} \\
\hline & \\
\hline www.ph & $\begin{array}{l}\text { DOI: } \\
\text { 10.5530/jyp.2015.4.10 }\end{array}$ \\
\hline
\end{tabular}

\section{INTRODUCTION}

Sickle cell disease is a genetic disorder affecting the haemaglobin. It is due to a transversion of adenine for thymine at the $6^{\text {th }}$ codon of the $\beta$ haemaglobin gene, resulting at the protein level in a substitution of the amino

*Address for correspondence:

Dr. André Tibiri, IRSS/CNRST, 03 BP 7192 Ouagadougou 03, Burkina Faso.

E-mail: tibiriandre@gmail.com 

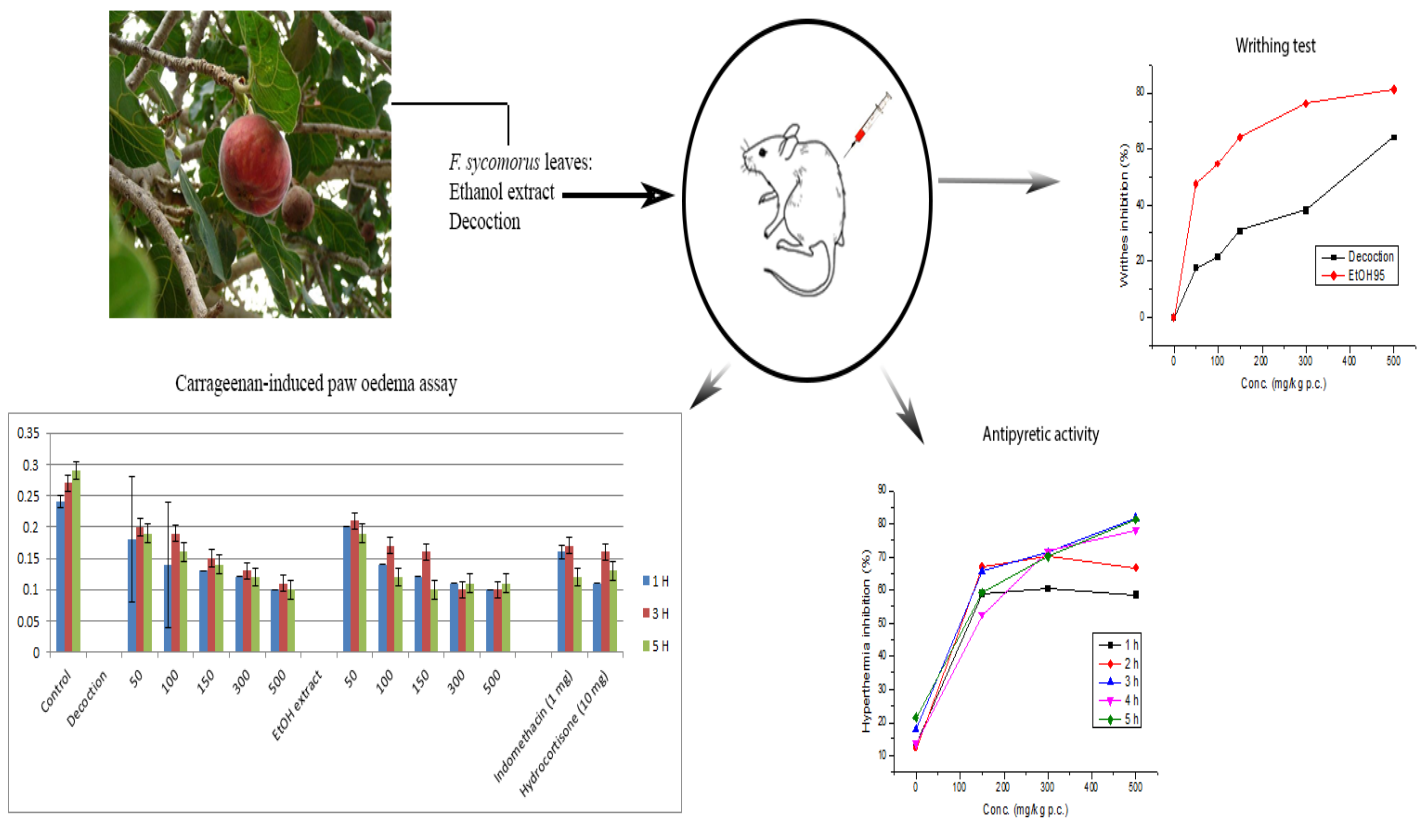

Graphical Abstract

acid glutamic acid for valine (HbS). ${ }^{1}$ The symptoms of sickle cell disease are dominated by painful vaso-occlusive crises with a significant inflammatory reaction. ${ }^{2}$ An example is the hand-foot syndrome in infants and young children less than 5 years old, characterised by a painful oedema on the dorsal side of the hands and feet. In $80 \%$ of cases, along with anaemia, this is the first reason for consultation. Fever, often caused by infection is also a factor which leads to vaso-occlusive crisis. ${ }^{3}$

Sickle cell disease is a major public health problem especially in sub-saharan Africa where around 50-80\% of the 400000 children born every year with this disorder die before the age of 5 years old. ${ }^{4}$ The ones who survive present with an attack on targeted organs (liver, heart, kidneys, eyes, bones, joints) which reduce the duration of life. The treatments used are anti-inflammatories, non-steroidal and steroidal (NSAIDs and SAIDs) which can generate potentially serious side effects over a long period of use: primarily digestive, but also renal, pulmonary or cutaneous. ${ }^{5}$ There is therefore a need for research on new molecules capable of acting on the mediators of inflammation, pain and fever with less side-effects.

Traditional medicine effectively participates in the treatment of sickle cell disease with plant based remedies that treat the recurring pathologies of the disorder, which are the painful crises, severe infections and anaemia. It is for this reason that there is a scientific interest to research these products and develop effective and widely accessible medicines for its management.
Ficus sycomorus stem bark and leaves are used in Burkina Faso folk medicine in the central plateau by the Mossi as decoction to alleviate sickle cell anemia crises. Previous work to date has shown anti-sickling properties, vasorelaxant effects together with a low toxicity level of Ficus sycomorus leaves that justify their use in traditional medicine in the treatment of sickle cell disease and its components. ${ }^{6}$ The objective of the present study is to evaluate the anti-inflammatory, analgesic and anti-pyretic effects of the total extracts of Ficus sycomorus leaves in the animal model.

\section{MATERIAL AND METHODS}

\section{Animals}

N.M.R.I. mice (males and females) from Institute for Research in Health Sciences (IRSS) weighing 26-37 g, were used. The mice were kept under a well-ventilated room at 25 $\pm 2^{\circ} \mathrm{C}$, with a relative humidity of $44-56 \%$ and light and dark cycles of $12 \mathrm{~h}$, respectively. They had free access to standard dry pellet diet (29\% protein) from the center of promotion of poultry farming (CPAVI, Bobo-Dioulasso) and to tap water ad libitum. The mice were fasted 18 hours before the experiments. All experiments were conducted in accordance with the internationally accepted principles for laboratory animaluse and care and the study protocole was approved by the Departement of medecine and traditional pharmacopea/ pharmacy (MEPHATRA/PH) of the Institute of Research in Health Sciences (IRSS), Burkina Faso. 


\section{Plant Material and preparation of the extracts}

The leaves of Ficus sycomorus were collected at the edge of Tanghin dam No2 (Sector 23, Ougadougou) in July 2009. After identification by the Professor of Botany Jeanne Millogo, a specimen was deposited in the herbarium of the University of Ouagadougou under the code $01 / 2009$. The plant material was dried in a ventilated room for 2 weeks, sheltered from the sun, and then finely ground.

The aqueous decoction $(10 \%)$ was prepared by reflux of 25 $\mathrm{g}$ of the leaves powder in $250 \mathrm{~mL}$ of distilled water for 30 min. After cooling, extract was filtered and centrifuged for $10 \mathrm{~min}$ at $2000 \mathrm{~g}$ (ALC 4217 Centrifuge) then they obtained supernatant was frozen and lyophilized (Lyophiliser ALPHA 1-2 LD Plus Sigma France).

The ethanol extract was prepared by adding $250 \mathrm{~mL}$ of $95 \%$ ethanol to $50 \mathrm{~g}$ of leaf powder. The mixture was allowed to rest for 24 hours at room temperature. After filtration, the solution obtained was evaporated $\left(50^{\circ}\right.$ under reduced pressure) in a Rotavapor (RE 111) equipped with a waterbath (Buchi-461) then frozen and lyophilised.

\section{Chemicals}

Lysine acetylsalicylate (LAS) was purchased from Sanofi Aventis (France). Indomethacin was purchased from Fluka Biochemika (Steinham, Switzerland). Brewer's Yeast (Saccharomyces cerevisiae) was from Arkopharma (France), Hydrocortisone was from Troika Apharmaceuticals Ltd. (Gujarat, India). Carrageen and Acetic acid were purchased from Sigma (France).

\section{Carrageenan-induced paw oedema assay}

The anti-oedematogenic effect was evaluated by the carrageenan-induced paw oedema method in mice, in accordance with the method of Winter CA, et al. ${ }^{7}$ with some minor modifications. Groups of six mice received the extracts (decoction and ethanol extract) orally in doses of $50,100,150,300$ and $500 \mathrm{mg} / \mathrm{kg}$ b.w. The control group received distilled water. An hour before drug administration, the oedema was induced by injection of carrageenan $(1 \% \mathrm{w} / \mathrm{v}$ in normal saline) into the plantar side of the right hind paw. Paw volume was measured with plethysmometer (Ugo Basile) one hour before the injection of carrageenan then $1 \mathrm{~h}, 3 \mathrm{~h}$ and $5 \mathrm{~h}$ after. Indomethacin $(1$ $\mathrm{mg} / \mathrm{kg}$ b.w) and Hydrocortisone (10 mg/ $\mathrm{kg}$ b.w) were used as reference substances and administered intraperitoneally. The mean oedema volume of the treated paw was calculated from three measurements with a deviation not exceeding $4 \%$. The anti-inflammatory activity was evaluated by the percentage of oedema reduction in the treated mice in comparison with the blank control group in accordance with the following formula:

$$
\% I=\frac{A-B}{A} \times 100
$$

Where $A$ is the mean difference in volume increase of the paw of the mice of the control; $B$ is the mean difference in volume increase of the paw in the treated groups.

\section{Analgesic Tests}

Acetic acid-induced writhing

The method was essentially as described by Nakamura H, et al. ${ }^{8}$ Groups of six mice were used. The control group received distilled water, while the other groups received the extracts (decoction and ethanol extract) at doses of 50 ; 100; 150; 300 and $500 \mathrm{mg} / \mathrm{kg}$ b.w. One hour after the oral administration of the extracts, the animals received acetic acid $(0.6 \%, \mathrm{v} / \mathrm{v}$ solution) intraperitoneally at a dose of 10 $\mathrm{mL} / \mathrm{kg}$ b.w. Five minutes after the injection of acetic acid, the number of abdominal writhings were counted for fifteen minutes. Lysine acetylsalicylate administered orally and hydrocortisone administered intraperitoneally were used as reference substances. The anti-nociceptive effect was expressed as percentage of inhibition of abdominal writhing.

Tail-flick test

This test explores the morphine type analgesic activity of substances by using a thermal stimulus: irradiation of the tail, which causes a pain inhibited by morphine type analgesics. It was conducted as described by Trongsakul et al. ${ }^{9}$ with slight modifications. Mice were placed on the tail-flick unit (Havard, Apparratus, USA), so that the tail occluded a slit over a photocell. Heat was applied by a 100-W lamp mounted in a reflector. The apparatus was arranged in such a way that when the operator turned on the lamp a timer was activated. When the mouse felt pain and flicked its tail, light fell on the photocell and then the timer was automatically stopped. The light intensity was adjusted to give a normal reaction time of $2-4$ s. A10-s cut-off time was used in order to prevent tissue damage. Groups of six mice were made, the control group received distilled water. Morphine at the dose of $5 \mathrm{mg} / \mathrm{kg}$ b.w. administered orally was used as reference drug. The other groups received the extracts (p.o)) at doses of 100; 150; 300 and $500 \mathrm{mg} / \mathrm{kg}$ b.w. The reflex time for tail removal was determined 15 minutes after administration of each dose and every 30 minutes for 2 hours, then after 3 hours. The analgesic response was calculated as a percentage of the maximum possible response time. 


\begin{tabular}{|c|c|c|c|}
\hline \multirow{2}{*}{$\begin{array}{c}\text { Group/Dose } \\
\text { (mg/kg) }\end{array}$} & \multicolumn{3}{|c|}{ Variation in oedema volume $(\Delta \mathrm{mL})$ and [percentage of inhibition $(\% \mathrm{l})]$} \\
\hline & 1 hour & 3 hours & 5 hours \\
\hline Control & $0.24 \pm 0.01$ & $0.27 \pm 0.01$ & $0.29 \pm 0.01$ \\
\hline \multicolumn{4}{|l|}{ Decoction } \\
\hline 50 & $0.18 \pm 01^{\star \# \bullet}(26.39)$ & $0.20 \pm 0.01^{* \# \bullet}(26.38)$ & $0.19 \pm 0.01^{* \# \bullet}(34.48)$ \\
\hline 100 & $0.14 \pm 01^{\text {*\#• }}(41.67)$ & $0.19 \pm 0.01^{*}(31.29)$ & $0.16 \pm 0.00^{* \# \bullet}(43.68)$ \\
\hline 150 & $0.13 \pm 00^{* \# \bullet}(45.83)$ & $0.15 \pm 0.00^{*}(44.79)$ & $0.14 \pm 0.00^{*}(51.72)$ \\
\hline 300 & $0.12 \pm 00^{* \#}(50.00)$ & $0.13 \pm 0.00^{* \#}(51.62)$ & $0.12 \pm 0.00^{*}(58.62)$ \\
\hline 500 & $0.10 \pm 00^{* \#(58.33)}$ & $0.11 \pm 0.00^{\star \#}(59.51)$ & $0.10 \pm 0.00^{* \bullet}(65.52)$ \\
\hline \multicolumn{4}{|l|}{ EtOH extract } \\
\hline 50 & $0.20 \pm 00^{* \# \bullet}(16.67)$ & $0.21 \pm 0.00^{* \# \bullet}(22.70)$ & $0.19 \pm 0.00^{* \# \bullet}(34.48)$ \\
\hline 100 & $0.14 \pm 00^{\star \# \bullet}(41.67)$ & $0.17 \pm 0.01^{*}(37.42)$ & $0.12 \pm 0.01^{*}(58.62)$ \\
\hline 150 & $0.12 \pm 00^{\star \#}(50.00)$ & $0.16 \pm 0.00^{*}(41.10)$ & $0.10 \pm 0.01^{\star \bullet}(65.52)$ \\
\hline 300 & $0.11 \pm 00^{\star \#}(54.17)$ & $0.10 \pm 0.01^{* \# \bullet}(63.19)$ & $0.11 \pm 0.00^{*}(62.07)$ \\
\hline 500 & $0.10 \pm 00^{* \#}(58.33)$ & $0.10 \pm 0.00^{* \# \bullet}(63.19)$ & $0.11 \pm 0.00^{*}(62.07)$ \\
\hline Indomethacin (1 mg) & $0.16 \pm 0.01^{*}(33.33)$ & $0.17 \pm 0.01^{*}(37.42)$ & $0.12 \pm 0.00^{*}(58.62)$ \\
\hline Hydrocortisone (10 mg) & $0.11 \pm 0.00^{*}(54.17)$ & $0.16 \pm 0.00^{*}(41.10)$ & $0.13 \pm 0.01^{\star}(55.17)$ \\
\hline
\end{tabular}

Values are expressed as mean $\pm \operatorname{SEM}(n=6) ;{ }^{*} p<0.05$ in comparison with the control group; ${ }^{*} p<0.05$ in comparison with the group treated with Indomethacin; ${ }^{\bullet} p<0.05$ in comparison with the group treated with hydrocortisone.

\section{Antipyretic test}

The antipyretic effect of the extracts was tested according to the method described by Sawadogo WR, et al. ${ }^{10}$ with minor modifications. Before the test, mice were weighed and their rectal temperature was taken $\left(\mathrm{T}_{-18 \mathrm{~h}}\right)$. Immediately after, the mice received an aqueous suspension of brewer's yeast $(20 \%$ $\mathrm{w} / \mathrm{v}$ ) subcutaneously in the dorso-lateral region at a dose of $1 \mathrm{~mL} / 100 \mathrm{~g}$ body weight and they were put to fast. 18 hours later the new rectal temperature was taken $\left(\mathrm{T}_{0 \mathrm{~h}}\right)$. Lots of six mice were made up of the mice who presented with a rise in temperature higher than or equal to $0.5^{\circ} \mathrm{C}$. The control group received distilled water, while the other groups received the extracts orally at doses of 150; 300 and $500 \mathrm{mg} / \mathrm{kg}$ b.w. LAS (300 mg/kg b.w., p.o) and hydrocortisone (10 mg/kg b.w., i.p) were used as reference drugs. The rectal temperature of animals was recorded at interval of $1 \mathrm{~h}$ for $5 \mathrm{~h}$ following the administration of drugs or extracts. The antipyretic activity was assessed according to the formula:

$$
\text { Inhibition }(\%)=\frac{\Delta T_{0}-\Delta T_{i}}{\wedge T} \times 100
$$

Where,

$$
\Delta T_{0}=T_{0 h}-T_{-18 h}
$$

is the variation of mean rectal temperature before antipyretic treatment.

$$
\Delta T_{i}=T_{i h}-T_{-18 h}
$$

is the variation of mean rectal temperature at time $i$ after antipyretic treatment.

\section{Statistical analysis}

The results of the different tests are expressed as mean \pm SEM. The comparison between the test groups and the control groups was carried out by the variance analysis test (ANOVA) followed by Dunnett's multiple comparaison test using GraphPad Prism version 6.01 for Windows, (GraphPad Software, La Jolla California USA www. graphpad.com). $P<0.05$ was considered as statistically significant.

\section{RESULTS}

\section{Carrageenan-induced paw oedema assay}

Table 1 shows the effect of the decoction and the ethanol extract of the leaves of Ficus sycomorus on the development of oedema. The two extracts exhibited an anti-oedematogenic effect at all doses tested, compared to the control group $(p<0.0001)$. The effect of the extracts was both dose dependent and time dependent. The maximum anti-oedematogenic activity of the decoction was obtained at the doses of 300 and $500 \mathrm{mg} / \mathrm{kg}$ b.w. after 5 hours, with an inhibiting effect of 58.62 and $65.52 \%$ respectively. The maximum inhibitory effect $(63.19 \%)$ of ethanol extract was obtained after 3 hours at doses of 300 and $500 \mathrm{mg} / \mathrm{kg}$ p.c. The effect observed was superior $(p<0.0001)$ to those observed in the reference groups indomethacin $(37.42 \%)$ and hydrocortisone $(41.10 \%)$. From 5 hours onwards the effects of the ethanol extract at doses of 300 and $500 \mathrm{mg} / \mathrm{kg}$ b.w. and the decoction at

Journal of Young Pharmacists Vol 7 • Issue 4 • Oct-Dec 2015 


\begin{tabular}{|c|c|c|}
\hline Group/Dose (mg/kg) & Number of writhes & Inhibition (\%) \\
\hline Control & $60.50 \pm 7.50$ & - \\
\hline \multicolumn{3}{|l|}{ Decoction } \\
\hline 50 & $49.83 \pm 3.42^{\# \bullet}$ & 17.63 \\
\hline 100 & $47.33 \pm 3.18^{\sharp \bullet}$ & 21.76 \\
\hline 150 & $41.83 \pm 4.96^{\star \# \bullet}$ & 30.85 \\
\hline 300 & $37.33 \pm 4.63^{\star \# \bullet}$ & 38.29 \\
\hline 500 & $21.67 \pm 5.08^{*}$ & 64.19 \\
\hline \multicolumn{3}{|l|}{ EtOH extract } \\
\hline 50 & $31.67 \pm 0.49^{\star \# \bullet}$ & 47.66 \\
\hline 100 & $27.33 \pm 5.95^{\star \#}$ & 54.82 \\
\hline 150 & $21.67 \pm 4.63^{*}$ & 64.19 \\
\hline 300 & $14.33 \pm 3.03^{\star}$ & 76.31 \\
\hline 500 & $11.33 \pm 1.75^{\star}$ & 81.27 \\
\hline LAS 300 mg & $7.17 \pm 2.20^{\star}$ & 88.15 \\
\hline Hydrocortisone (10 mg) & $10.50 \pm 2.08^{*}$ & 82.64 \\
\hline
\end{tabular}

$300 \mathrm{mg} / \mathrm{kg}$ p.c were comparable to those of the reference groups. At the same time, the decoction at $500 \mathrm{mg} / \mathrm{kg}$ b.w. resulted in a higher $(p<0.001)$ inhibition of oedema by than that of hydrocortisone (55.17\%).

\section{Analgesic activity}

\section{Acetic acid-induced writhing}

The two extracts (decoction and ethanol extract) caused a significant $(p<0.05)$ dose-dependent reduction of acetic acid induced abdominal writhing in the mice, in comparison with the control (Table 2). At the dose of $500 \mathrm{mg} / \mathrm{kg}$ b.w., the decoction caused an inhibition in abdominal writhing of $64.20 \%$. This value was comparable with the reference groups LAS (300 mg/kg b.w.) and hydrocortisone (10 mg/ $\mathrm{kg} \mathrm{b.w.)} \mathrm{with} \mathrm{inhibitions} \mathrm{of} 88.15$ and $82.64 \%$ respectively. The ethanol extract given at $150 \mathrm{mg} / \mathrm{kg}$ b.w. caused an inhibition in contractions at a level comparable with the two reference groups.

\section{Tail-flick test}

The results of the morphine type analgesic activity by tail-flick reflex in mice are shown in Table 3. The effect of the extracts and reference drugs were dose-dependent and increased with time. During the first quarter of an hour, the ethanol extract at doses of 300 and $500 \mathrm{mg} / \mathrm{kg}$ b.w. showed a significant $(p<0.05)$ analgesic effect compared to the control with an inhibition of 38.34 and $48.94 \%$ respectively. After 105 minutes and until the end of the test $(180 \mathrm{~min})$ the analgesic effect of the ethanol extract was significant at all the doses compared to the control group and was also comparable with those of the morphine group. The decoction showed a significant $(p<0.05)$ analgesic effect in comparison with the control, only at doses of 300 and
$500 \mathrm{mg} / \mathrm{kg}$ p.c. The effect was also comparable to that of morphine from 75 minutes.

Anti pyretic activity

The results showing the antipyretic effects of the two extracts on induced hyperthermia by brewer's yeast are presented in Table 4. The inhibitory effect was dosedependent. Antipyretic activity of the decoction was significant $(\phi<0.05)$ for doses of 300 and $500 \mathrm{mg} / \mathrm{kg}$ b.w. reaching a maximum by $3 \mathrm{~h}$ after treatment with inhibitory effect of 69.85 and $75.68 \%$ respectively. The level of inhibition of induced hyperthermia is thus comparable to those of the references LSA and hydrocortisone and was maintained until the end of treatment. The antipyretic effect of the ethanol extract was more pronounced than the decoction, with an inhibitory effect more than $50 \%$ in the first hour and a maximum of $81.78 \%$ at a dose of 500 $\mathrm{mg} / \mathrm{kg}$ after 3 hours. The inhibition caused by the ethanol extract at all doses and at all times was of a level comparable to those of the two reference groups. The extracts and also the reference drugs showed a slight decrease of their effect from the fourth hour, although they remained significantly increased in comparison to the control until the fifth hour.

\section{DISCUSSION}

The carrageenan-induced oedema assay is a widely used method for testing anti-inflammatory substances in the animal model. The oedema observed during the inflammatory process is caused by a vasodilation and increase in vascular permeability due to the release of various inflammatory mediators such as histamine, serotonin, bradykinin and prostaglandins. These mediators 
Table 3: Effects of aqueous decoction and ethanol extract of Ficus sycomorus L. leaves tail-flick reflex in mice

\begin{tabular}{|c|c|c|c|c|c|c|}
\hline \multirow{2}{*}{$\begin{array}{c}\text { Group/Dose } \\
\text { (mg/kg) }\end{array}$} & \multicolumn{6}{|c|}{ Reaction time and [Inhibition (\%l)] } \\
\hline & $15 \min$ & $45 \mathrm{~min}$ & $75 \mathrm{~min}$ & $105 \mathrm{~min}$ & $120 \mathrm{~min}$ & $180 \mathrm{~min}$ \\
\hline Control & $0.89 \pm 0.17$ & $0.80 \pm 0.03$ & $0.74 \pm 0.07$ & $0.69 \pm 0.04$ & $0.71 \pm 0.02$ & $0.69 \pm 0.06$ \\
\hline \multicolumn{7}{|l|}{ Decoction } \\
\hline 100 & $\begin{array}{c}0.69 \pm 0.04 \\
(-27.88)^{\#}\end{array}$ & $0.88 \pm 0.07(8.75)^{\#}$ & $\begin{array}{c}0.84 \pm 0.02 \\
(11.95)^{\#}\end{array}$ & $\begin{array}{c}0.81 \pm 0.11 \\
(15.43)^{\#}\end{array}$ & $\begin{array}{c}0.83 \pm 0.09 \\
(14.80)^{\#}\end{array}$ & $\begin{array}{c}1.27 \pm 0.07 \\
(45.32)^{\#}\end{array}$ \\
\hline 150 & $0.95 \pm 0.09(6.17)^{\#}$ & $1.05 \pm 0.12(23.93)$ & $\begin{array}{c}1.02 \pm 0.10 \\
(27.90)^{\#}\end{array}$ & $\begin{array}{c}1.07 \pm 0.12 \\
(35.98)^{\#}\end{array}$ & $1.29 \pm 0.09(44.89)$ & $1.35 \pm 0.08(48.64)$ \\
\hline 300 & $0.94 \pm 0.05(5.51)^{\#}$ & $1.20 \pm 0.13(33.15)$ & $\begin{array}{c}1.43 \pm 0.07 \\
(48.60)^{*}\end{array}$ & $\begin{array}{c}1.64 \pm 0.08 \\
(58.15)^{\star}\end{array}$ & $\begin{array}{c}1.59 \pm 0.14 \\
(55.25)^{*}\end{array}$ & $\begin{array}{c}1.81 \pm 0.14 \\
(61.79)^{*}\end{array}$ \\
\hline 500 & $1.32 \pm 0.11(32.83)$ & $\begin{array}{c}1.69 \pm 0.26 \\
(52.66)^{*}\end{array}$ & $\begin{array}{c}1.75 \pm 0.02 \\
(57.82)^{*}\end{array}$ & $\begin{array}{c}1.76 \pm 0.22 \\
(61.08)^{*}\end{array}$ & $\begin{array}{c}1.81 \pm 0.26 \\
(60.77)^{\star}\end{array}$ & $\begin{array}{c}2.53 \pm 0.62 \\
(72.61)^{*}\end{array}$ \\
\hline \multicolumn{7}{|l|}{ EtOH extract } \\
\hline 100 & $0.83 \pm 0.11(-7.26)^{\#}$ & $1.22 \pm 0.05(34.16)$ & $1.29 \pm 0.15(42.82)$ & $\begin{array}{c}1.60 \pm 0.10 \\
(57.23)^{*}\end{array}$ & $\begin{array}{c}1.75 \pm 0.05 \\
(59.35)^{\star}\end{array}$ & $\begin{array}{c}1.84 \pm 0.10 \\
(62.34)^{*}\end{array}$ \\
\hline 150 & $1.26 \pm 0.26(29.52)$ & $1.42 \pm 0.16(43.74)$ & $\begin{array}{c}1.51 \pm 0.14 \\
(51.21)^{*}\end{array}$ & $\begin{array}{c}1.65 \pm 0.12 \\
(58.38)^{*}\end{array}$ & $\begin{array}{c}1.97 \pm 0.30 \\
(63.89)^{*}\end{array}$ & $\begin{array}{c}1.91 \pm 0.25 \\
(63.82)^{*}\end{array}$ \\
\hline 300 & $\begin{array}{c}1.44 \pm 0.19 \\
(38.34)^{*}\end{array}$ & $\begin{array}{c}1.72 \pm 0.27 \\
(53.60)^{*}\end{array}$ & $\begin{array}{c}1.54 \pm 0.25 \\
(52.16)^{*}\end{array}$ & $\begin{array}{c}1.61 \pm 0.27 \\
(57.45)^{*}\end{array}$ & $\begin{array}{c}1.96 \pm 0.25 \\
(63.78)^{*}\end{array}$ & $\begin{array}{c}1.89 \pm 0.23 \\
(63.33)^{*}\end{array}$ \\
\hline 500 & $\begin{array}{c}1.74 \pm 0.09 \\
(48.94)^{\star}\end{array}$ & $\begin{array}{c}2.08 \pm 0.40 \\
(61.60)^{*}\end{array}$ & $\begin{array}{c}1.72 \pm 0.21 \\
(57.13)^{\star}\end{array}$ & $\begin{array}{c}2.16 \pm 0.31 \\
(68.26)^{\star}\end{array}$ & $\begin{array}{c}2.12 \pm 0.37 \\
(66.46)^{\star}\end{array}$ & $\begin{array}{c}1.96 \pm 0.09 \\
(64.68)^{\star}\end{array}$ \\
\hline Morphine (5 mg) & $\begin{array}{c}1.46 \pm 0.10 \\
(39.41)^{\star}\end{array}$ & $\begin{array}{c}1.74 \pm 0.13 \\
(54.02)^{*}\end{array}$ & $\begin{array}{c}1.86 \pm 0.21 \\
(60.48)^{*}\end{array}$ & $\begin{array}{c}2.06 \pm 0.15 \\
(66.72)^{*}\end{array}$ & $\begin{array}{c}1.98 \pm 0.15 \\
(64.11)^{*}\end{array}$ & $\begin{array}{c}2.35 \pm 0.31 \\
(70.59)^{\star}\end{array}$ \\
\hline
\end{tabular}

Values are expressed as mean $\pm \operatorname{SEM}(n=6) ;{ }^{*} p<0,05$ in comparison with the control group; ${ }^{\#} p<0.05$ en in comparison with the group treated with morphine.

\begin{tabular}{|c|c|c|c|c|c|c|c|}
\hline \multirow{3}{*}{$\begin{array}{c}\text { Group/Dose } \\
(\mathrm{mg} / \mathrm{kg})\end{array}$} & \multicolumn{7}{|c|}{ Rectal temperature $\left({ }^{\circ} \mathrm{C}\right)$} \\
\hline & \multicolumn{7}{|c|}{ Time after medication and [inhibition (\%)] } \\
\hline & T-18 & TO & $1 \mathrm{~h}$ & $2 \mathrm{~h}$ & $3 \mathrm{~h}$ & $4 \mathrm{~h}$ & $5 \mathrm{~h}$ \\
\hline Control & $38.19 \pm 0.14$ & $38.95 \pm 0.22$ & $38.85 \pm 0.25$ & $38.86 \pm 0.25$ & $38.81 \pm 0.24$ & $38.85 \pm 0.17$ & $38.79 \pm 0.20$ \\
\hline \multicolumn{8}{|l|}{ Decoction } \\
\hline 150 & $37.64 \pm 0.15$ & $38.24 \pm 0.18$ & $\begin{array}{c}38.11 \pm 0.14^{\bullet} \\
(20.92)\end{array}$ & $\begin{array}{c}38.10 \pm 0.14^{\star * \bullet} \\
(23.43)\end{array}$ & $\begin{array}{c}38.08 \pm 0.17^{\# \bullet} \\
(26.78)\end{array}$ & $\begin{array}{c}37.98 \pm 0.021^{* \bullet} \\
(42.68)\end{array}$ & $\begin{array}{c}37.97 \pm 0.23^{* \bullet} \\
(45.19)\end{array}$ \\
\hline 300 & $37.28 \pm 0.19$ & $38.88 \pm 0.22$ & $\begin{array}{c}37.97 \pm 0.26^{\star \bullet} \\
(55.85)\end{array}$ & $\begin{array}{c}37.72 \pm 0.18^{\star \bullet} \\
(71.23)\end{array}$ & $\begin{array}{c}37.74 \pm 0.20^{*} \\
(69.85)\end{array}$ & $\begin{array}{c}37.79 \pm 0.17^{*} \\
(67.08)\end{array}$ & $\begin{array}{c}37.71 \pm 0.18^{*} \\
(71.69)\end{array}$ \\
\hline 500 & $37.25 \pm 0.32$ & $38.91 \pm 0.21$ & $\begin{array}{c}37.96 \pm 0.26^{\star \bullet} \\
(51.22)\end{array}$ & $\begin{array}{c}37.70 \pm 0.18^{\star \bullet} \\
(65.14)\end{array}$ & $\begin{array}{c}37.51 \pm 0.29^{*} \\
(75.68)\end{array}$ & $\begin{array}{c}37.54 \pm 0.34^{*} \\
(74.05)\end{array}$ & $\begin{array}{c}37.54 \pm 0.35^{*} \\
(73.92)\end{array}$ \\
\hline \multicolumn{8}{|l|}{ EtOH extract } \\
\hline 150 & $37.15 \pm 0.09$ & $37.93 \pm 0.14$ & $\begin{array}{c}37.54 \pm 0.13^{*} \\
(58.85)\end{array}$ & $\begin{array}{c}37.49 \pm 0.12^{*} \\
(66.92)\end{array}$ & $\begin{array}{c}37.50 \pm 0.11^{*} \\
(65.77)\end{array}$ & $\begin{array}{c}37.58 \pm 0.13^{*} \\
(52.69)\end{array}$ & $\begin{array}{c}37.54 \pm 0.08^{*} \\
(59.23)\end{array}$ \\
\hline 300 & $37.06 \pm 0.03$ & $38.17 \pm 0.10$ & $\begin{array}{c}37.55 \pm 0.03^{*} \\
(60.59)\end{array}$ & $\begin{array}{c}37.45 \pm 0.06^{*} \\
(70.44)\end{array}$ & $\begin{array}{c}37.44 \pm 0.09^{*} \\
(71.43)\end{array}$ & $\begin{array}{c}37.44 \pm 0.11^{*} \\
(71.67)\end{array}$ & $\begin{array}{c}37.45 \pm 0.08^{*} \\
(70.20)\end{array}$ \\
\hline 500 & $37.29 \pm 0.14$ & $38.52 \pm 0.29$ & $\begin{array}{c}37.80 \pm 0.32^{*} \\
(58.50)\end{array}$ & $\begin{array}{c}37.70 \pm 0.25^{\star \bullet} \\
(66.80)\end{array}$ & $\begin{array}{c}37.51 \pm 0.28^{*} \\
(81.78)\end{array}$ & $\begin{array}{c}37.56 \pm 0.23^{*} \\
(78.14)\end{array}$ & $\begin{array}{c}37.52 \pm 0.27^{*} \\
(81.38)\end{array}$ \\
\hline LAS (300 mg) & $37.16 \pm 0.06$ & $37.84 \pm 0.02$ & $\begin{array}{c}37.37 \pm 0.11^{*} \\
(67.52)\end{array}$ & $\begin{array}{c}37.24 \pm 0.08^{*} \\
(87.23)\end{array}$ & $\begin{array}{c}37.24 \pm 0.08^{*} \\
(86.50)\end{array}$ & $\begin{array}{c}37.24 \pm 0.08^{*} \\
(86.50)\end{array}$ & $\begin{array}{c}37.26 \pm 0.06^{*} \\
(84.31)\end{array}$ \\
\hline $\begin{array}{l}\text { Hydrocortisone } \\
\qquad(10 \mathrm{mg})\end{array}$ & $37.03 \pm 0.11$ & $37.80 \pm 0.07$ & $\begin{array}{c}37.18 \pm 0.02^{*} \\
(79.68)\end{array}$ & $\begin{array}{c}37.11 \pm 0.01^{*} \\
(89.35)\end{array}$ & $\begin{array}{c}37.10 \pm 0.06^{*} \\
(90.65)\end{array}$ & $\begin{array}{c}37.12 \pm 0.02^{*} \\
(88.06)\end{array}$ & $\begin{array}{c}37.12 \pm 0.01^{*} \\
(87.74)\end{array}$ \\
\hline
\end{tabular}

Values are expressed as mean $\pm \operatorname{SEM}(n=6) ;{ }^{*} p<0,05$ in comparison with the control group; $\# p<0.05$ in comparison with the group treated with LAS $; \bullet p<0.05$ in comparison with the group treated with hydrocortisone

are involved at different stages. Histamine and serotonin are released early during the first hour, ${ }^{11}$ the inflammatory responses of bradykinin and the prostaglandins come after. ${ }^{12}$ The effect of the prostaglandins is prolonged for over three hours ${ }^{13}$ The two types of extract, decoction and ethanol extract inhibited oedema in a dose-dependent manner at all stages, suggesting an antagonistic action with regards to the different mediators of inflammation. The inhibitory effect was most pronounced from the third hour, suggesting an inhibition biased towards the cyclo oxygenases responsible for the production of prostaglandins. 
The non-morphine type analgesic effect of the extracts was evaluated by acetic acid-induced writhing in mice. The algesic effect of acetic acid is associated with the release of endogenous substances that stimulate the nociceptive peripheral nerve endings. ${ }^{14}$ The two types of Ficus sycomorus leaf extract at doses of 300 and $500 \mathrm{mg} / \mathrm{kg}$ b.w. caused a reduction of more than $50 \%$ in the number writhes. The action of the ethanol extract is more significant than that of LAS and hydrocortisone. LAS is a Non-steroidal antiinflammatory drug (NSAID) capable of inhibiting the cyclooxygenases in the peripheral tissues, interfering with the mechanism of pain transduction in afferent nociceptive nerves. ${ }^{15}$ Hydrocortisone, as with the majority of Steroidal anti-inflammatory drugs (SAIDs) has the effect of reducing the chemical effectors of inflammation (prostaglandins and leukotrienes) through inhibition of phospholipase $\mathrm{A}_{2}$, serotonin and histamine. ${ }^{16}$ The analgesic effect of the ethanol extract could be explained by a blocking or relaxation of the effect of the endogenous substances that stimulate nociceptive nerve endings, similar to LAS or hydrocortisone.

The tail-flick test is commonly used to evaluate the morphine type analgesic effect. The response of the animal to tail irradiation is a spinal reflex that involves the central nervous system. ${ }^{17}$ At a dose of 300 and 500 $\mathrm{mg} / \mathrm{kg}$ b.w., the decoction and the ethanol extract showed response times that were similar to those of morphine, suggesting therefore an analgesic effect of the morphine type.

The hyperthermia induced by brewer's yeast follows the release of cytokines that stimulate the bio-synthesis of prostaglandins $\left(\mathrm{PGE}_{2}\right.$ ) within the thermo regulating region of the hypothalamus. ${ }^{18}$ The results showed the antipyretic effect of the two extract types, the ethanol extract being more pronounced in comparison to the reference substances LAS and hydrocortisone.

The evaluation of anti-inflammatory activity of plant extracts in the context of the treatment of sickle cell disease is essential. In addition to the genetic mutation resulting in abnormal synthesis of haemoglobin, pain, oedema and fever are essential characteristics in this disorder. ${ }^{19}$ The significance of sickle-cell pain is such that this symptom alone often epitomizes the disease. ${ }^{20}$ Different inflammatory agents such as cytokines $(\mathrm{TNF} \alpha)$ are often increased in sickle cell patients, thus vasodilation and vascular permeability resulting from a massive production of $\mathrm{TNF} \alpha$, lead to significant oedema, characterised by the hand-foot syndrome amongst small children affected by sickle cell disease, one of the first reasons for consultation. ${ }^{21}$ Other anti-inflammatory agents such as interleukines (IL-1) are also increased amongst these patients, causing the synthesis of $\mathrm{PGE}_{2}$ and inducing fever. ${ }^{22}$ Repeated infections also result in fevers and trigger vaso-occlusive crises. ${ }^{3}$ Additionally, the hyper gammaglobulinaemia ( $\operatorname{IgG}$ and $\operatorname{IgM}$ ) observed in children affected by sickle cell disease shows the existence of a permanent state of inflammation in comparison with healthy subjects living in the same environment. ${ }^{23}$

Mandal SC, et al. ${ }^{24}$ and Fleurentin $\mathrm{J}^{25}$ have shown that phenolic compounds (tannins and flavonoids) are effective in the inhibition of the different stages of inflammation and in the inhibition of the release of pro-inflammatory mediators (histamine, serotonin) and of cyclo-oxygenase. These compounds are capable of interfering with the biosynthesis of prostaglandins as do the salicylates and NSAIDs. ${ }^{26}$ Many studies ${ }^{27,28}$ have shown the presence of tannins, flavonoids and flavonols in the leaves of Ficus sycomorus, which could explain the anti-inflammatory action of the two types of extracts presented here. The presence of alkaloids, ${ }^{28,29}$ which are compounds recognised for their action on the central nervous system, could equally explain the morphine-type analgesic effect observed.

\section{CONCLUSION}

The results obtained by this study have shown the antiinflammatory and anti-nociceptive properties of the leaves of Ficus sycomorus. These findings provide a scientific basis justifying the use of this plant in traditional medicine in the treatment of sickle cell disease and show the significance of this plant in the search for new anti-inflammatory molecules for the treatment of sickle cell disease.

\section{ACKNOWLEDGEMENTS}

This study was self-funded by the authors. We acknowledge the chief of the Department of traditional medicine and pharmacopeia for facilitating the research work to be carried out in his laboratories.

\section{CONFLICTS OF INTEREST}

Authors declared there is no Conflict of interest. 


\section{Highlights of Paper}

- Ficus sycomorus L. (Moraceae) is used in traditional medicine in Burkina Faso for the management of sickle cell disease, a pathology characterized by painful vaso-occlusive crises with a significant inflammatory reaction.

- The administration of the crude extracts of the leaves (decoction and ethanol extract) in mice caused significant anti-oedematogenic, analgesic and antipyretic effects.

- The two types of extracts, at the dose of 300 and $500 \mathrm{mg} / \mathrm{kg} \mathrm{b.w}$. caused an inhibition rate of the anti-inflammatory effects between 50 and $80 \%$.

- The anti-inflammatory activity of the extracts is shown by an antagonistic effect of various mediators of inflammation, primarily against prostaglandins.

\section{Author Profile}

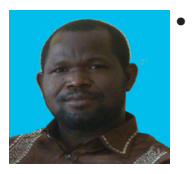

Dr. André Tibiri : Researcher in biochemistry and phytochemistry at the Institute of research in health sciences, department of traditional medicine. His works focus on the valorization of the traditional medicine receipts, including cancer, infectious and inflammatory diseases. Dr. Tibiri is author of 11 research papers and 8 vulgarization cards.

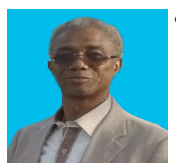

Pr. Innocent Pierre Guissou : Professor of pharmacology-toxicology, University of Ouagadougou. Responsible of the doctoral school at the training unit and health sciences research (UFR/SDS), coordinator of the 3rd cycle of pharmacology and toxicology.He is also the Head of the CHU-YO hospital pharmacy. Pr. Guissou is author of more than 100 journal papers, several communications and conferences.

\section{REFERENCES}

1. Rees DC, Williams TN, Gladwin MT. Sickle-cell disease. Lancet 2010; 376(9757): 2018-31.

2. Monnet D, Edjeme NE, Ndri K, Hauhouot-Attoungbre ML, Ahibo $\mathrm{H}$, Sangare $\mathrm{A}$, et al. Lipoprotein (a) and acute phase inflammation proteins in homozygous sickle cell disease. Ann Biol Clin (Paris). 2002; 60(1): 101-3.

3. Kravis E, Fleisher G, Ludwig S. Fever in children with sickle cell hemoglobinopathies. Arch Pediatr Adolesc Med. 1982; 136(12): 1075.

4. OMS: Compendium des stratégies de santé publique. In Book Compendium des stratégies de santé publique (Editor ed.^eds.), vol. 1. City: Bureau Régionale de l'Afrique; 2012.

5. Gabriel SE, Jaakkimainen L, Bombardier C. Risk for serious gastrointestinal complications related to use of nonsteroidal anti-inflammatory drugsa meta-analysis. Ann Intern Med. 1991; 115(10): 787-96.

6. Ramde-Tiendrebeogo A, Tibiri A, Ouedraogo M, Ouedraogo S, Nacoulma OG, Guissou IP. Study of Antisickling and Vasorelaxant Activities and Acute Toxicity Assessment of Crude Extracts of Leaves of Ficus sycomorus L. (Moraceae). Pak J Biol Sci. 2014; 17(6): 829-35.

7. Winter CA, Risley EA, Nuss GW. Carrageenin-induced edema in hind paw of the rat as an assay for antiiflammatory drugs. Proc Soc Exp Biol Med. 1962; 111(3): 544-7.

8. Nakamura H, Shimoda A, Ishii K, Kadokawa T. Central and peripheral analgesic action of non-acidic non-steroidal antiinflammatory drugs in mice and rats. Arch Int Pharmacodyn Ther. 1986; 282(1): 16-25.

9. Trongsakul S, Panthong A, Kanjanapothi D, Taesotikul T. The analgesic, antipyretic and anti-inflammatory activity of Diospyros variegata Kruz. J Ethnopharmacol. 2003; 85(2): 221-5.

10. Sawadogo WR, Boly R, Lompo M, Some N, Lamien CE, Guissou IP, et al. Anti-inflammatory, Analgesic and Antipyretic Activities of Dicliptera verticillata. Int J Pharmacol. 2006; 2(4): 435-8.

11. Cuzzocrea $S$, Zingarelli B, Hake P, Salzman AL, Szabo C. Antiinflammatory effects of mercaptoethylguanidine, a combined inhibitor of nitric oxide synthase and peroxynitrite scavenger, in carrageenan-induced models of inflammation. Free Radical Biol Med. 1998; 24(3): 450-9.

12. Ueno A, Naraba H, Ikeda $Y$, Ushikubi F, Murata T, Narumiya S, Oh-ishi S. Intrinsic prostacyclin contributes to exudation induced by bradykinin or carrageenin: a study on the paw edema induced in IP-receptor-deficient mice. Life Sci. 2000; 66(12): PL155-60.

13. Reanmongkol W, Noppapan T, Subhadhirasakul S. Antinociceptive, antipyretic, and anti-inflammatory activities of Putranjiva roxburghii Wall. leaf extract in experimental animals. J Nat Med. 2009; 63(3): 290-6.

14. Raj PP. Pain medicine: a comprehensive review. Mosby Inc; 1996.

15. Fields $\mathrm{H}$. Analgesic drugs. In: Day W, editor. Pain $1^{\text {st }}$ ed. USA: Mac-Graw-Hill; 1987. p. 272.

16. Newton R. Molecular mechanisms of glucocorticoid action: what is important? Thorax. 2000; 55(7): 603-13.

17. Gray WD, Osterberg AC, Scuto TJ. Measurement of the analgesic efficacy and potency of pentazocine by the D'Amour and Smith method. J Pharmacol Exp Ther. 1970; 172(1): 154-62.

18. Begum S, Saxena B, Goyal M, Ranjan R, Joshi VB, Rao CV, et al. Study of anti-inflammatory, analgesic and antipyretic activities of seeds of Hyoscyamus niger and isolation of a new coumarinolignan. Fitoterapia 2010; 81(3): 178-84.

19. Girot R. Present status of sickle cell anemia. Arch Fr Pediatr. 1986; 43(1): 83-6.

20. Platt OS, Thorington BD, Brambilla DJ, Milner PF, Rosse WF, Vichinsky E, Kinney TR. Pain in sickle cell disease: rates and risk factors. New Engl J Med.1991; 325(1): 11-6.

21. Lambotte C. Hand-foot syndrome in sickle-cell disease. Arch Pediatr Adolesc Med. 1962; 104(4): 200.

22. Etienne-Julan M, Belloy MS, Decastel M, Dougaparsad S, Ravion $S$, Hardy-Dessources MD. Childhood sickle cell crises: clinical severity, inflammatory markers and the role of interleukin-8. Haematologica 2004; 89(7): 863-4.

23. Baum KF, Dunn DT, Maude GH, Serjeant GR. The painful crisis of homozygous sickle cell disease. A study of the risk factors. Arch Intern Med. 1987; 147(7): 1231-4.

24. Mandal SC, Maity TK, Das J, Saba BP, Pal M. Anti-inflammatory evaluation of Ficus racemosa Linn. leaf extract. J Ethnopharmacol. 2000; 72(1): 87-92.

25. Fleurentin J. Les plantes médicinales de la Pharmacopée française. Ethnopharmacologia : bulletin de la Société française d'ethnopharmacologie et de la Société européenne d'ethnopharmacologie 2002; 1(1): 41-73.

26. Vergne $P$, Bertin $P$, Trèves R. Aspirine, douleurs et inflammation Re Méd Interne. 2000; 21(1): S89-96.

Journal of Young Pharmacists Vol $7 \bullet$ Issue $4 \bullet$ Oct-Dec 2015 
27. Abdel-Hameed E-S. Total phenolic contents and free radical scavenging activity of certain Egyptian Ficus species leaf samples. Food Chem. 2009; 114(4): 1271-7.

28. Ramde-Tiendrebeogo A, Tibiri A, Hilou A, Lompo M, Millogo-Kone $\mathrm{H}$, Nacoulma $\mathrm{O}$, et al. Antioxidative and antibacterial activities of phenolic compounds from Ficus sur Forssk. and Ficus sycomorus
L.(Moraceae): potential for sickle cell disease treatment in Burkina Faso. Int J Biol Chem Sci. 2012; 6(1): 328-36.

29. Sandabe UK, Onyeyili PA, Chibuzo GA. Phytochemical screening and effect of aqueous extract of Ficus sycomorus $L$. (Moraceae) stembark on muscular activity in laboratory animals. J Ethnopharmacol. 2006; 103(1): 481-3. 